\title{
Characterization of Poly-\{trans-[RuCl$\left.\left(\mathrm{Vpy}_{4}\right)_{4}\right]$-styrene-4-vinylpyridine\} Impregnated with Silver Nanoparticles in Non Aqueous Medium
}

\author{
Karen Segala, ${ }^{* a}$ Rosilene L. Dutra, ${ }^{a, c}$ Eric N. de Oliveira, ${ }^{a}$ Liane M. Rossi, ${ }^{b}$ Jivaldo R. Matos, ${ }^{b}$ \\ Marcos M. S. Paula ${ }^{c}$ and César V. Franco ${ }^{*, a}$ \\ ${ }^{a}$ Departamento de Química, Universidade Federal de Santa Catarina, Campus Trindade, \\ 88040-900 Florianópolis - SC, Brazil \\ ${ }^{b}$ Instituto de Química, Universidade de São Paulo, Av. Prof. Lineu Prestes, 748, Cidade Universitária, \\ 05508-000 São Paulo - SP, Brazil
}

${ }^{c}$ Departamento de Engenharia de Materiais, Universidade do Extremo Sul Catarinense, Av. Universitária, 1105, 88806-000 Criciúma-SC, Brazil

\begin{abstract}
A síntese e a caracterização de um novo filme polimérico composto por poli- $\{$ trans$\left[\mathrm{RuCl}_{2}(\mathrm{vpy})_{4}\right]$-estireno-4-vinilpiridina\} impregnado com nanopartículas de prata são descritas neste trabalho. Este material foi obtido por polimerização em meio não aquoso envolvendo o complexo mononuclear trans-[ $\left.\mathrm{RuCl}_{2}(\mathrm{vpy})_{4}\right]$, o estireno (sty) e a 4-vinilpiridina (4-vpy), usando peróxido de benzoila como iniciador. As dimensões nanométricas das partículas de prata foram confirmadas através de microscopia eletrônica de transmissão (TEM) e por espectroscopia eletrônica no UV-visível. A morfologia do terpolímero foi caracterizada por microscopia eletrônica de varredura (MEV). As propriedades térmicas foram analisadas por termogravimetria (TGA) e calorimetria diferencial de varredura (DSC). A ação antimicrobiana do polímero impregnado com nanopartículas de prata foi avaliada utilizando microrganismos Gram positivo e Gram negativo, Staphylococcus aureus (ATCC 25923) e Escherichia coli (ATCC 25922), respectivamente. A atividade antimicrobiana do terpolímero com nanopartículas de prata foi confirmada pela presença de um halo de inibição do crescimento bacteriano nos meios de cultura semeados.
\end{abstract}

The synthesis and characterization of a new polymeric material composed of poly-\{trans$\left[\mathrm{RuCl}_{2}(\mathrm{vpy})_{4}\right]$-styrene-4-vinylpyridine $\}$ impregnated with silver nanoparticles are here described. This material was obtained by a non aqueous polymerization reaction involving trans$\left[\mathrm{RuCl}_{2}(\mathrm{vpy})_{4}\right]$, styrene (sty) and 4-vinylpyridine (4-vpy), using benzoyl peroxide as initiator. The silver particles nanometric dimensions were confirmed by transmission electron microscopy (TEM) and UV-visible spectroscopy. The terpolymer morphology was characterized by scanning electron microscopy (SEM). Thermal properties were analyzed by thermal gravimetric analysis (TGA) and differential scanning calorimetry (DSC). The antimicrobial action of the polymer impregnated with silver nanoparticles was evaluated by the use of Gram positive and Gram negative microorganisms, Staphylococcus aureus (ATCC 25923) and Escherichia coli (ATCC 25922), respectively. The antimicrobial activity of the terpolymer with silver nanoparticles was confirmed by the presence of a bacterial growth inhibition halo in seeded culture media.

Keywords: ruthenium complex, polymer, silver nanoparticles, antimicrobial

\section{Introduction}

Functional polymer networks have gained great importance in many fields of scientific research as well as in industrial applications. These applications will

*e-mail: karen@qmc.ufsc.br; franco@qmc.ufsc.br increase greatly due to the variety of possible modifications in the chemical and physical properties of these materials. ${ }^{1}$ Network polymers based on styrene, prepared by well-developed suspension polymerization processes, retain many advantageous qualities for a microcomposite host matrix. These include ease of preparation, controlled surface area and porous structure, 
good thermal resistance and reasonable chemical inertness. ${ }^{2}$ Polymers based on the application of coordination forces have been prepared recently. The first direct synthesis of a polymer containing a transition metal complex gave rise to a coordination polymer based on ruthenium(II)-terpyridine complexes and was described recently in the literature. ${ }^{3-5}$

Research has also been intensive in antibacterial materials containing various organic and inorganic substances. Among them, silver and silver ions have long been known to have strong inhibitory and bactericidal effects, as well as a broad spectrum of antimicrobial activities, ${ }^{6}$ and have therefore been seen as candidates for the coating of medical devices. Although various coatings using silver salts or metallic silver have been reported, they have shown in most cases disappointing clinical results. Impregnation of polymers with silver has emerged as an alternative and promises to lead to materials with increased antimicrobial activity. ${ }^{7}$ In this communication we describe the preparation of an antimicrobial material based on the terpolymer poly- $\left\{\right.$ trans- $\left[\mathrm{RuCl}_{2}(\mathrm{vpy})_{4}\right]-$ sty4-vpy\} impregnated with silver nanoparticles in non aqueous medium.

\section{Experimental}

The synthetic methods used to produce both precursors, the ruthenium blue solution and trans$\left[\mathrm{RuCl}_{2}(\mathrm{vpy})_{4}\right]$, are described elsewhere. ${ }^{8,9}$

High quality silver nanoparticles were prepared by thermal decomposition of $50 \mathrm{mg}(0.3 \mathrm{mmol})$ of silver nitrate in the presence of $2.5 \mathrm{~mL}$ ( $7.5 \mathrm{mmol}$ ) of oleylamine added to $50 \mathrm{~mL}$ of diphenylether under stirring. The mixture was heated to reflux and kept at this temperature for 3 hours. The color of the dispersion changed to light yellow then to orange and finally to dark brown as the reaction proceeded. The particles were precipitated with ethanol and separated by centrifugation $(6000 \mathrm{rpm} / 30$ $\mathrm{min})$, resulting in a dark solid. After repeating the washing procedure for 3 times, the solid was dried under vacuum and suspended in $10 \mathrm{~mL}$ of toluene (stock solution).

The terpolymer poly- $\left\{\right.$ trans-[ $\left[\mathrm{RuCl}_{2}(\mathrm{vpy})_{4}\right]$-sty-4-vpy $\}$ was synthesized under argon from $0.26 \mathrm{mmol}(0.1 \%)$ of $\left[\mathrm{RuCl}_{2}(\mathrm{vpy})_{4}\right], 0.13 \mathrm{~mol}$ of styrene and $0.13 \mathrm{~mol}$ of 4-vinylpyridine added to a dispersion of silver nanoparticles in toluene. Benzoyl peroxide was employed as initiator. The system was maintained under reflux, with vigorous mechanical stirring, at a temperature of $120^{\circ} \mathrm{C}$ for 2 hours.

Microbiological studies were performed to investigate the antimicrobial activity of this new material. The cells of Escherichia coli (ATCC 25922) were reactivated from a stock culture and their purity was confirmed by seeding in McConkey Agar. For Staphylococcus aureus (ATCC 25923) this inspection was carried out in Manitol Ágar. After 24 hours, the samples of E. coli and S. aureus were placed in Brain Heart Infusion (BHI) and 0.9\% saline solution, respectively. The concentration of the bacteria was controlled to $10^{6} \mathrm{CFU} / \mathrm{mL}$ and they were then seeded in Muller \& Hynton culture medium. The samples of the polymer impregnated with silver nanoparticles were placed in a Petri dish with the Muller \& Hynton culture medium seeded with the microorganisms and incubated at $37^{\circ} \mathrm{C}$ overnight.

\section{Results and Discussions}

The oleylamine-capped silver nanoparticles form very stable yellow dispersions in toluene. The nanometric dimension of the silver particles was confirmed through transmission electron microscopy (TEM) and UV-visible spectroscopy (Figure 1a and b). The electronic spectrum recorded from a toluene dispersion of silver nanoparticles showed a single symmetric absorption band around 410 $\mathrm{nm}$ that corresponds to the characteristic surface plasmon resonance band of spherical silver particles. ${ }^{10} \mathrm{~A}$ characteristic feature of noble metal nanoparticles is the strong color of their colloidal dispersions, which is determined by the surface plasmon absorption. The surface plasmon resonance is a consequence of the reduced particle size, since it is absent in the individual atoms as well as in the bulk material, and its maximum wavelength and bandwidth are dependent on size, morphology and composition in different extents. ${ }^{10}$

Analysis of the TEM micrographs confirmed the spherical shape of the silver nanoparticles and revealed a bimodal particle size distribution with average diameters of 9 and $15 \mathrm{~nm}$ estimated by measuring the diameter of 600 randomly selected particles in enlarged TEM images. The histogram of Figure 1c shows the particle size distribution fitted by two Gaussian curves.

The polymer surface morphology was characterized by scanning electron microscopy (SEM), showing a polymeric material with a smooth surface and an increased roughness in the polymer impregnated with silver. TEM analysis of ultra-thin sections of the impregnated polymer revealed the silver nanoparticles dispersed in the polymeric matrix (Figure 2). Results of thermogravimetric analysis (TGA) and differential scanning calorimetry (DSC) of the terpolymer poly- $\left\{\right.$ trans- $\left[\mathrm{RuCl}_{2}(\mathrm{vpy})_{4}\right]$-sty-4-vpy $\}$ with and without silver nanoparticles are shown in Figure 3. TG curves of both materials showed similar thermal behaviour 

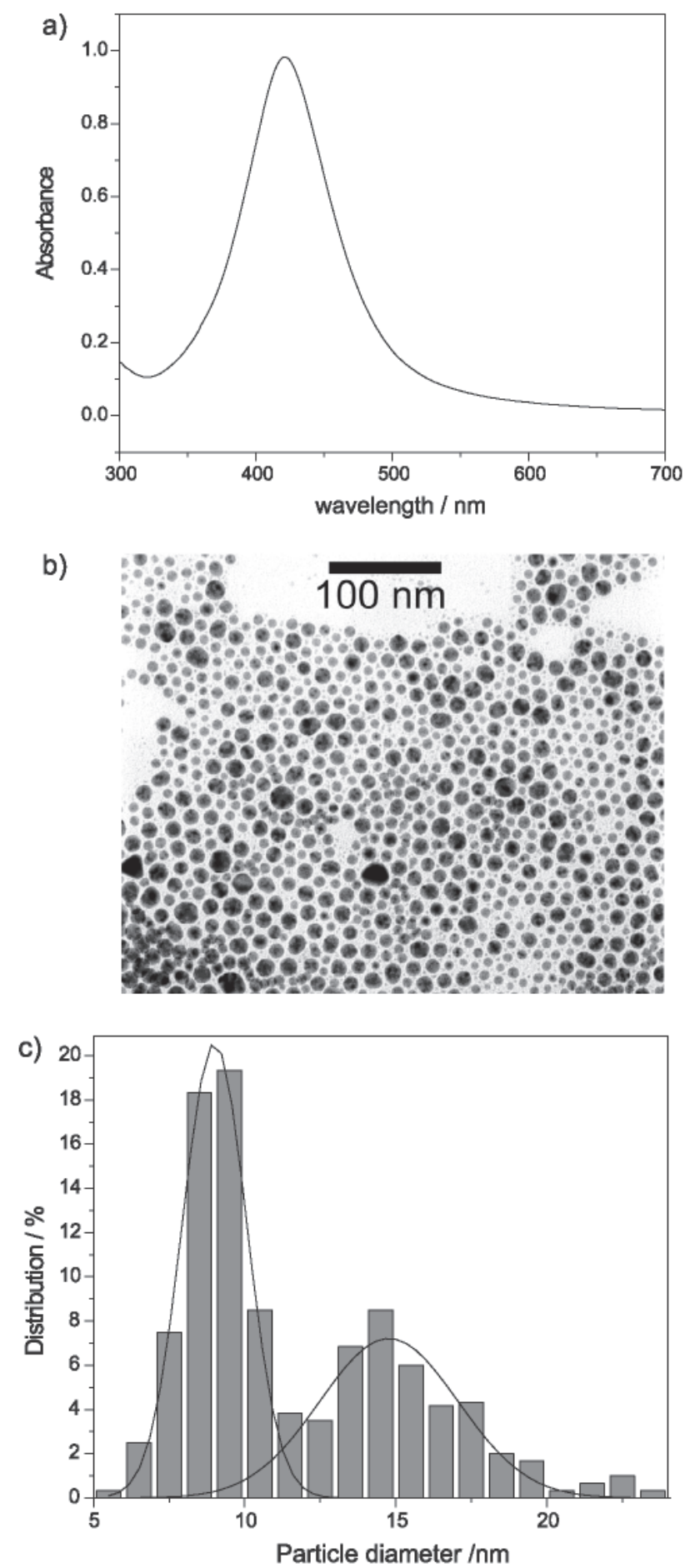

Figure 1. (a) UV-visible spectrum of silver nanoparticules in toluene; (b) TEM micrograph; (c) histogram showing the particle size distribution.

with total mass loss of $99.40 \%$ (without silver) and $99.06 \%$ (with silver) in the interval from 25 to $700{ }^{\circ} \mathrm{C}$. A slightly lower mass loss in the polymer impregnated with silver is consistent with the presence of the non volatile metallic component in the polymeric matrix. The DSC curve for the terpolymer without silver revealed an endothermic process from 25 to $110^{\circ} \mathrm{C}\left(\mathrm{T}_{\text {peak }} \mathrm{DSC}=69^{\circ} \mathrm{C}\right)$ that can be attributed to the loss of free components (monomers, oligomers) or solvent molecules. The DSC curve for the terpolymer impregnated with silver revealed an endothermic process between 105 and $190{ }^{\circ} \mathrm{C}$ $\left(\mathrm{T}_{\text {peak }} \mathrm{DSC}=123^{\circ} \mathrm{C}\right)$ not observed in the terpolymer free of silver. This process can be attributed to the loss of the weakly bound oleylamine capping ligands from the silver nanoparticle surfaces. The main endothermic process, which corresponds to the terpolymer decomposition, occurred between 295 and $450{ }^{\circ} \mathrm{C}$ for both materials. However, the DSC curves indicate endothermic events at $367{ }^{\circ} \mathrm{C}$ for the terpolymer without silver and at $381{ }^{\circ} \mathrm{C}$ for the terpolymer impregnated with silver. This behaviour demonstrates stabilization of the terpolymer due to the presence of silver metal in the polymeric matrix. After three successive heating cycles in the interval from 25 to $200{ }^{\circ} \mathrm{C}$ it was possible to estimate a glass transition at $156{ }^{\circ} \mathrm{C}$ for the terpolymer and at $84{ }^{\circ} \mathrm{C}$ for the terpolymer impregnated with silver. The presence of silver decreased the glass transition of the terpolymer as expected.

The polymer samples impregnated with silver nanoparticles were placed in a Petri dish with the Muller \& Hynton culture medium with Escherichia coli (ATCC 25922) and Staphylococcus aureus (ATCC 25923). A bacterial growth inhibition halo was observed around the polymer impregnated with silver which has not been observed in the polymer without silver (Figure 4). The inhibition halo diameter was 11 and $12 \mathrm{~mm}$ for E.coli and $S$. aureus respectively. This growth inhibition caused by the presence of silver nanoparticles in the polymer reveals the antiseptic properties of the material.

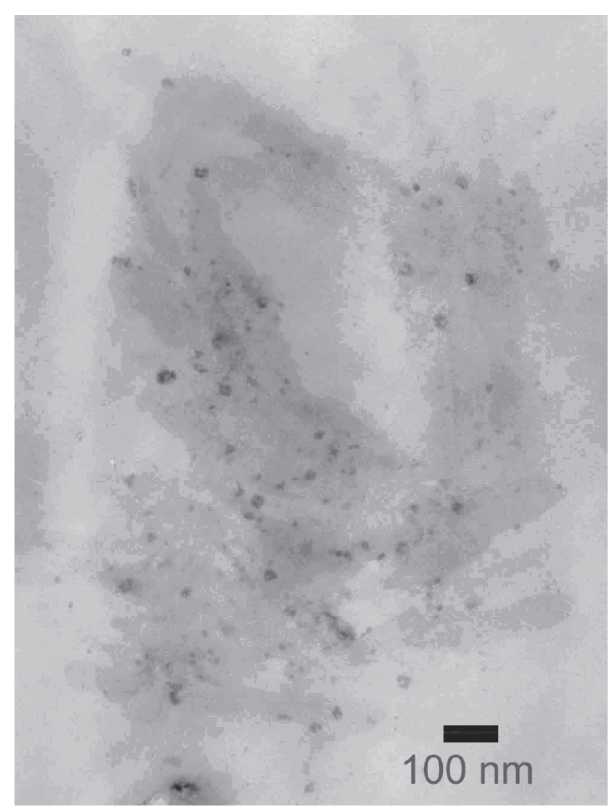

Figure 2. TEM micrograph of an ultra-thin section of the terpolymer impreganted with silver nanoparticles. 


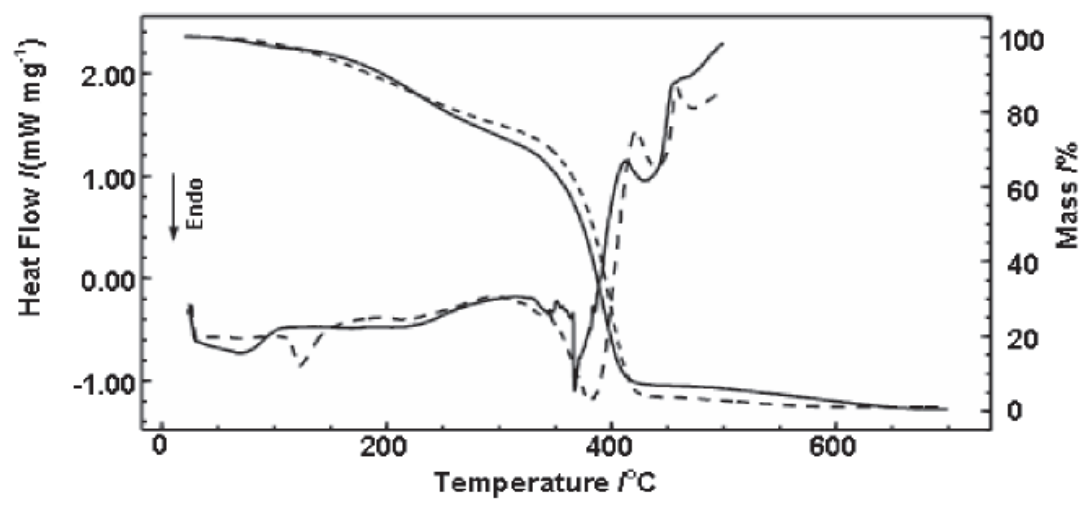

Figure 3. TG and DSC curves obtained at $10^{\circ} \mathrm{C} \mathrm{min}^{-1}$ and under dynamic $\mathrm{N}_{2}$ atmosphere for the terpolymer poly- $\left\{\right.$ trans-[RuCl $2\left(\mathrm{vpy}_{4}\right]$-sty-4-vpy $\}$ impregnated with silver nanoparticles (dashed line) and without silver (solid lines).

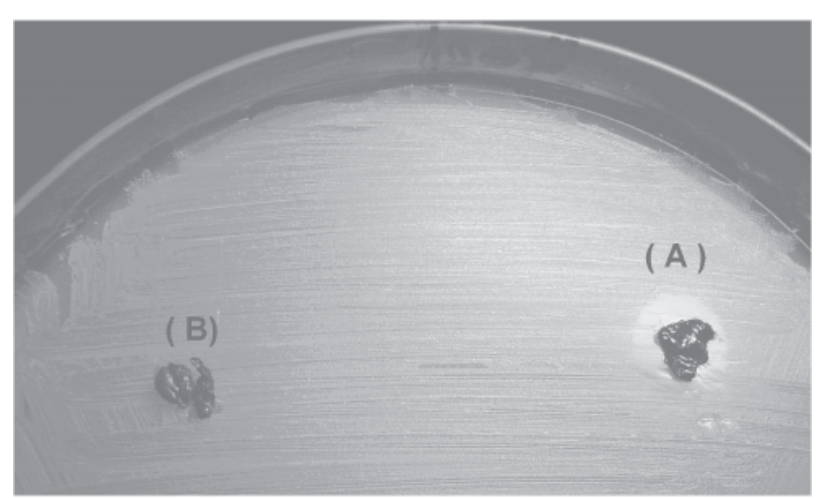

Figure 4. Antimicrobial activity of the terpolymer poly-\{trans$\left[\mathrm{RuCl}_{2}(\mathrm{vpy})_{4}\right]$-sty-4-vpy\} (A) with and (B) without silver nanoparticles.

\section{Conclusions}

The ternary polymer poly- $\left\{\right.$ trans- $\left[\mathrm{RuCl}_{2}(\mathrm{vpy})_{4}\right]$-sty4-vpy \} was prepared and impregnated with silver nanoparticles through a one-step chemical reaction using benzoyl peroxide as initiator and involving all monomers and the nanoparticles dispersed in toluene. We have developed a completely new approach using polymerization in non aqueous medium for uniform distribution of the nanoparticles throughout the polymeric matrix. Preliminary microbiological analysis showed an inhibition halo of bacterial growth around the polymer impregnated with silver nanoparticles in the microculture plates, confirming the antiseptic property of the material. The complete characterization and the microbiological studies of this new material will be discussed in a further report.

\section{Acknowledgments}

The authors acknowledge the financial support from CNPq CT-Saúde, contract 504436/2004-0. Rosilene L. Dutra, Eric Oliveira and Karen Segala thank CNPq for fellowships. We also thank Hospital Universitário-UFSC/ $\mathrm{SC}$, which made laboratory materials and space available.

\section{References}

1. Struck, M.; Wilddeeke, H.; Angew, D.; Makromol. Chem. 1996, 235, 131 .

2. Santa Maria, L.C.; Leite, M.C.A.M.; Costa, M.A.S.; Ribeiro, J.M.S.; Senna, L.F.; Silva, M.R.; Mater. Lett. 2004, 58, 94.

3. Kelch, S.; Rehan, M.; Macromolecules 1999, 32, 5818.

4. Lohmeijer, B.G.G.; Schubert, U.S.; Polym. Mater. Sci. Eng. 2001, 85, 460.

5. Franco, C.V.; Paula, M.M.S.; Goulart., G.; De Lima, L.F.C.P.; Noda, L.K.; Gonçalves, N.S.; Mater. Lett. 2006, 60, 2549.

6. Cho, K-H.; Park, J-E.; Osaka, T.; Park, S-G.; Electrochim. Acta 2005, 51, 956.

7. Furno, F.; Morley, K. S.; Wong, B.; Sharp, B. L.; Arnold, P. L.; Howdle, S. M.; Bayston, R.; Brown, P. D.; Winship, P. D.; Reid, H. J.; J. Antimicrob. Chemother. 2004, 54, 1019.

8. Franco, C. V.; De Moraes Jr., V. N.; Mocellin, F.; Paula, M.M.S.; J. Mater.Chem. 1998, 8, 2049.

9. Bandeira, M.C.E.; Prochnow, F.D.; Noda, L.K.; Gonçalves, N.S.; Costa, I.; De Melo, H.G.; Crayston, J.A. ; Franco, C. V.; J. Solid State Electrochem. 2004, 8, 244.

10. Jiang, L. P.; Xu, S.; Zhu, J. M.; Zhang, J. R.; Zhu, J. J.; Chen, H. Y.; Inorg. Chem. 2004, 43, 5877.

Received: June 13, 2006 Published on the web: December 1, 2006 